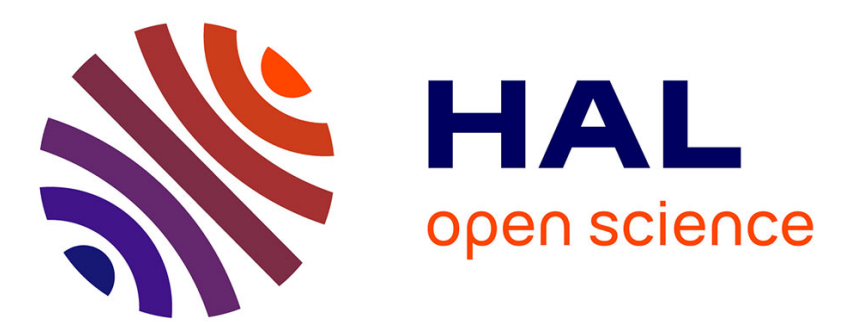

\title{
Study of small distorsions in Bi12MO20 oxides by simple exafs transmission technics
}

M. H. Tuilier, Michel Devalette, N. Khachani, M. Dexpert, Pierre Lagarde

\section{To cite this version:}

M. H. Tuilier, Michel Devalette, N. Khachani, M. Dexpert, Pierre Lagarde. Study of small distorsions in Bi12MO20 oxides by simple exafs transmission technics. Journal de Physique Colloques, 1986, 47 (C8), pp.C8-741-C8-744. 10.1051/jphyscol:19868140 . jpa-00226041

\section{HAL Id: jpa-00226041 https://hal.science/jpa-00226041}

Submitted on 1 Jan 1986

HAL is a multi-disciplinary open access archive for the deposit and dissemination of scientific research documents, whether they are published or not. The documents may come from teaching and research institutions in France or abroad, or from public or private research centers.
L'archive ouverte pluridisciplinaire HAL, est destinée au dépôt et à la diffusion de documents scientifiques de niveau recherche, publiés ou non, émanant des établissements d'enseignement et de recherche français ou étrangers, des laboratoires publics ou privés. 


\title{
STUDY OF SMALL DISTORSIONS IN $\mathrm{Bi}_{12} \mathrm{MO}_{20}$ OXIDES BY SIMPLE EXAFS TRANSMISSION TECHNICS
}

\author{
M.H. TUILIER* ${ }^{* * *}$, M. DEVALETTE ${ }^{*}$, N. KHACHANI ${ }^{*}$, \\ M. DEXPERT ${ }^{*}$ and P. LAGARDE* \\ *LURE (MEN, CNRS, CEA), Bâtiment 209D, Université de Paris-Sud, \\ F-91405 Orsay Cedex, France \\ ** Laboratoire de Chimie du Solide, CNRS, F-33405 Talence Cedex. \\ France \\ *** Laboratoire de Physique et de spectrométrie Electronique. \\ F-68093 Mulhouse, France
}

RESunE : Dans certaines phases de type sillénites $8{ }_{12}\left[A_{\alpha}^{+x} B_{B}^{+y}\right] 0_{20}$, les distances interatomiques entre T'oxygène et les cations $A$ et a localisés dans les sites tétraédriques de la structure ont été déterminées par EXAFS et ce, malgré les difficultés d'enregistrement dues à la concentration relativement faible des espèces $A$ et $B$ en présence de bismuth fortement absorbant.

ABSTRACT : In some $B i{ }_{2}\left[A_{\alpha}^{+x} B_{B}^{+y}\right] 0_{20}$ sillenite type phases the interatomic distances between oxygen and $A$ or 8 cations located in tetrahedral sites of the lattice can be determined by EXAfS despite difficult recording conditions due to relatively low concentrations of $A$ and $B$ species in presence of strong absorbing bismuth.

Single crystals of $\mathrm{Bi}_{12} \mathrm{SiO}_{20}$ and $\mathrm{Bi}_{12} \mathrm{GeO}_{20}$ pure or doped present very interesting electro-optical properties.

The $\mathrm{Bi}{ }^{\mathrm{MO}}$ sillenite phases crystallize in a body centered cubic lattice (space group $123, Z=$ 2) (1). The $h^{2}$ cation located at the corners and the center of the cube is surrounded by perfect oxygen tetrahedra. When $M$ is substituted by $A$ and $B$ cations, isostructural phases $B{ }_{12}\left[A_{\alpha}^{+x} B_{B}^{+y}\right]_{0}$ are obtained (2). In this case, the crystallographical investigation leads only to average $(A-B)-0$ distances. EXAFS seemed an appropriate tool for determining more precisely the concerned bond lengths.

\section{EXPERIMENTAL PROCEDURE ARO DATA AMALYSIS}

The X-ray absorption spectra of powdered $B i_{12}[G e] O_{20}, B{ }_{12}\left[\mathrm{As}_{4 / 5}^{+V} \mathrm{O}{ }_{1 / 5}\right] \mathrm{O}_{20}, \mathrm{Bi}_{12}\left[\mathrm{Zn}_{1 / 3}+\mathrm{II}_{\mathrm{As}}+\mathrm{V} / 3 \mathrm{YO}_{20}\right.$

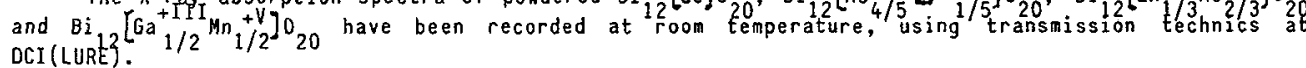

Due to the strong absorption of bismuth at the corresponding photon energies ( 9500 to $12500 \mathrm{eV}$ ) and the low concentration of $A$ or $B$ cations (less than 1 for 12 bismuth atons) the thickness of the samples has to be carefully adjusted.

Let us call $\mu_{1}$ and $\mu_{2}$ the respective absorption coefficients below and above the $K$ absorption edge for the various cations present ( $G e, A s, Z n, G a$ ) and $x$ the thickness of the sample. The optimum thickness conditions is $\mu_{2} x \simeq 2$ at the absorption edge of interest. But this requirement can yet be fulfilled as the value of the contrast $\left(\mu_{2}-\mu_{1}\right) \times$ should be generally too low to be detected. However, whereas the determination of the number of neighbours requires generally the best possible conditions for data recording, the first shell radius can be considered as a lower linit here due to the critical measuring conditions. Hence, we have adjusted the thickness of the samples so that $\mu_{2} x \simeq 4$, which, in each case leads to a sufficient contrast (i.e. $\left(\mu_{2}-\mu_{1}\right) x>0.1$.

$3^{T h e} X(E)$ data for Ge,As,Ga,Zn at the $K$-edge are given in Fig.1. The window used for the $F . I$. of the $k^{3} X(k)$ data extended for all samples from $30 \mathrm{eV}$ to $450,300,270$ and $220 \mathrm{eV}$ for Ge, As, Ga and $Z n$ respectively. 
The back transforned contribution of the first oxygen coordination shell has been calculated using theoritical amplitude and phase shift.

Since the distance between germanium and oxygen are known in $B{ }_{12} / G_{0} / 0_{20}$ from the classical crystallographic data, we have used this compound to check the validity of our data treatment method. The value of Ge-0 distance is found to be $1.77 \AA$, value which very well agrees with $X$-ray diffraction.

For the zinc compound which give the worst experimental data, we have selected Zno (wurtzite) as a reference compound. We have found the the $2 n-0$ distance was unchanged using a window either from 30 to 600 eV or extending from 30 to $220 \mathrm{eV}$.
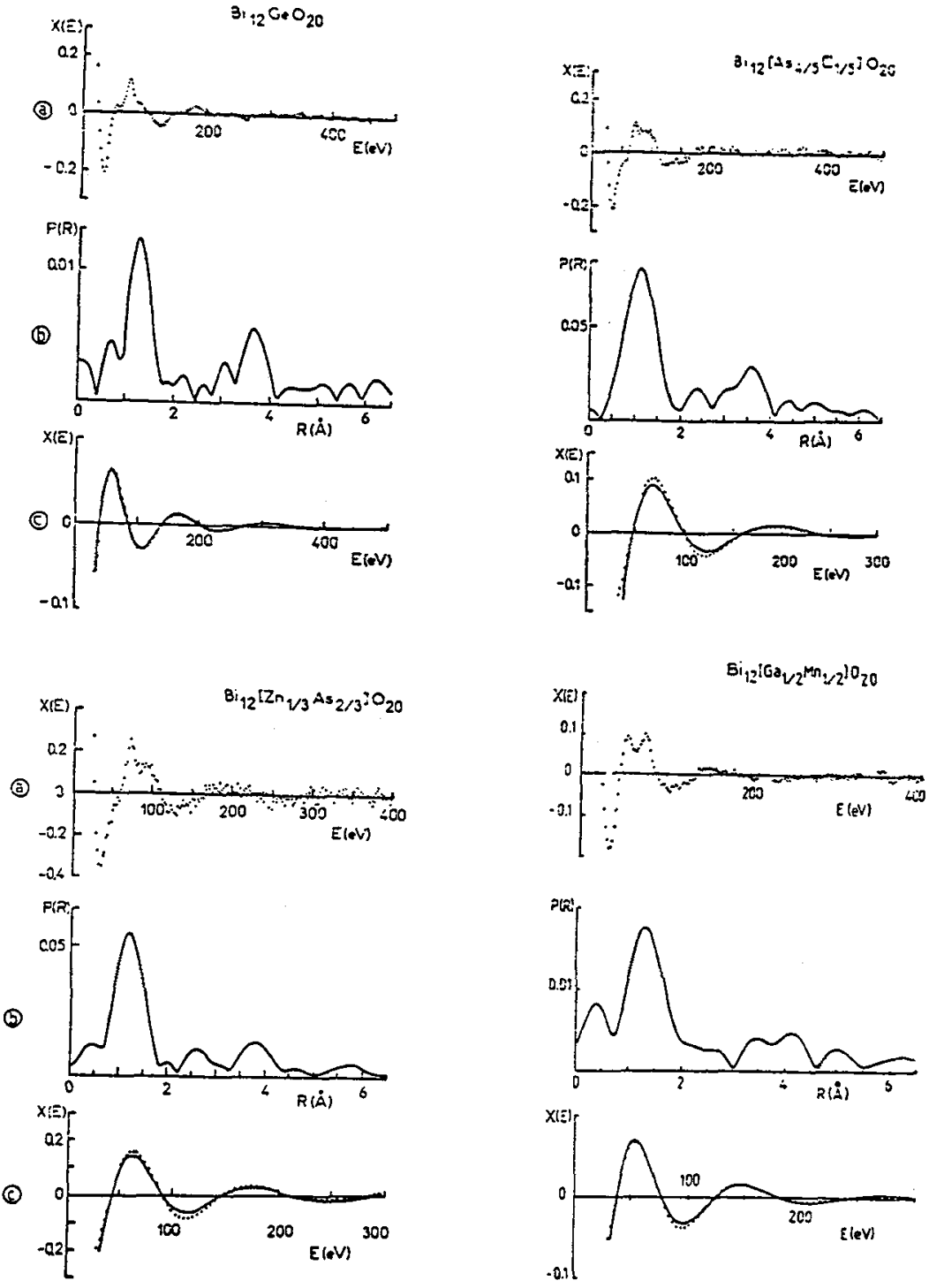

Fig.1 - a) EXAFS spectrum of the studied compounds above the Ge, As, $Z n, G a$ K-edge.

b) Radial distribution function (without phase shift correction).

c) Back-fourier transformed contribution of the first neighbour shell : exp.(points), calc.(full line). 
(e)

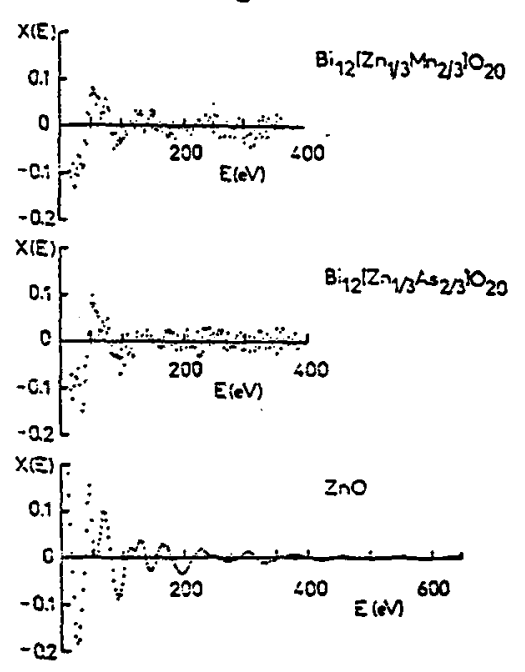

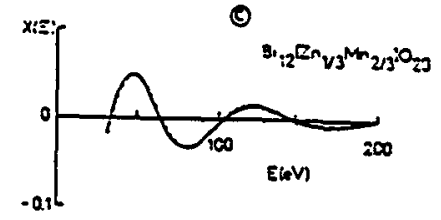
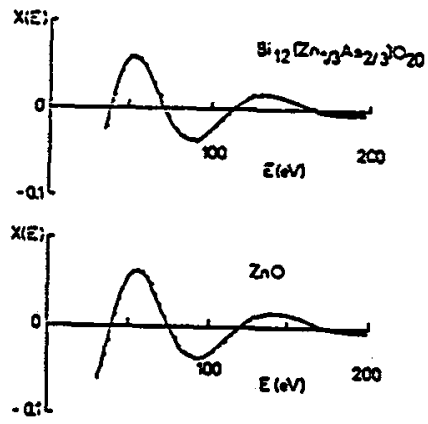

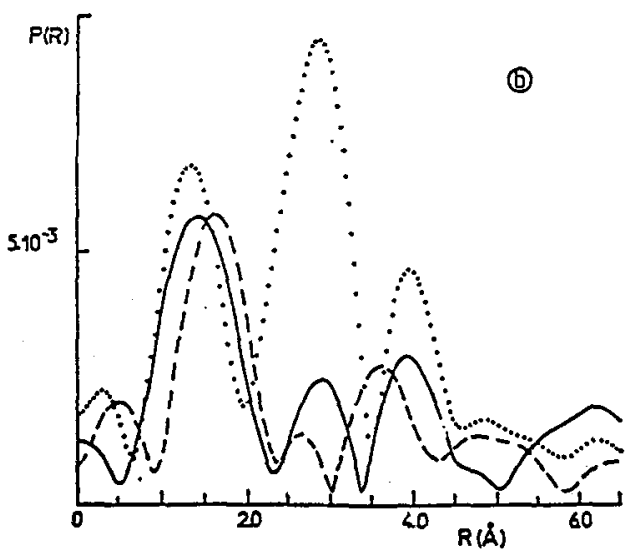

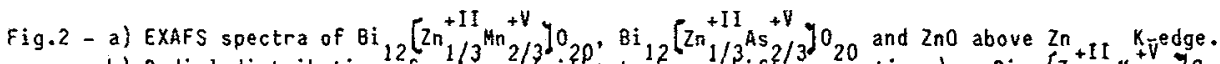

b) Radial distribution functions (without phase shift corrections) : $8 i_{12}\left[\mathrm{Zn}_{1 / 3}^{+\mathrm{HI}} \mathrm{Hn}_{2 / 3}^{+\mathrm{V}}\right]_{20}$ (full line), $8 \mathrm{i}\left[\mathrm{Zn}_{1 / 3}^{+1 \mathrm{As}} \mathrm{As}_{2 / 3}^{+V}\right] \mathrm{O}_{20}$ (dashed line), Zno (points).

c) Back-fourler transformed contributions of the first neighbour shell : exp. (points), calc. (full line).

\section{RESULTS}

The results obtained are summarized in Table $I$.

In spite of the presence in the materials of a high number of strongly absorbing bismuth atoms, ExAFs has allowed to determine some interatomic distances between oxygen and $A$ and (or) $B$ cations located in the tetrahedral sites of the sillenite type structure.

The most valuable result has been obtained for the $\left.B i_{12}\left[Z n_{1}^{+I I} A_{S}^{+V}\right]_{2}\right]_{20}$ oxide for which the $Z n-0$ and $A s-0$ distances are respectively $1.83 \AA$ and $1.71 \AA$. The difference between those values clearly shows that the tetrahedra cannot be identical in the lattice when they are occupied by different cations. 
TABLE - Comparaison of EXAFS results with crystallographic data.

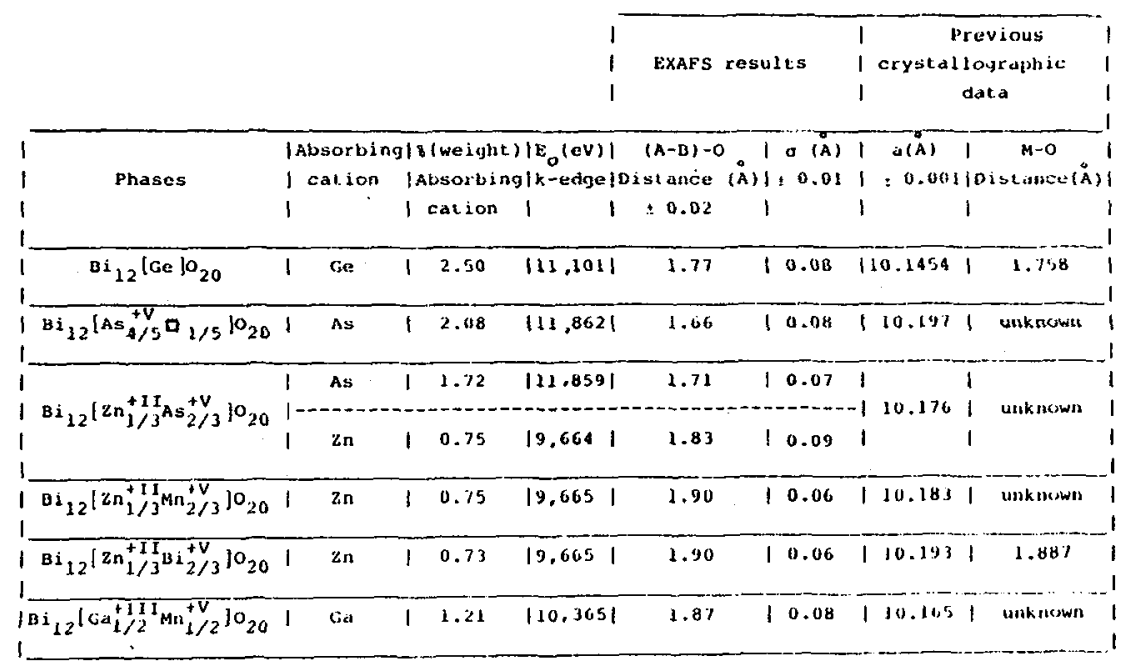

\section{REFEREMCES}

(1) agrahams S.C., JaMIESON P.B., Bernstein J.L., J. Chem. Phys., 47, n०10, 4034 (1967).

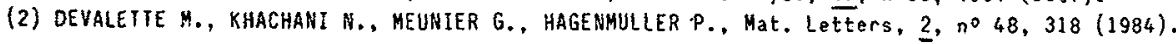

